\title{
A ntibacterial activity of actinomycetes against bacterial pathogens of diabetic foot ulcers
}

\author{
M. Saraswathi ${ }^{2 *}$ and N. M allikarjuna ${ }^{1}$ \\ ${ }^{1}$ Department of Microbiology, S.V.University, Tirupati-517 501, INDIA \\ ${ }^{2}$ Department of Applied Microbiology, Sri Padmavati Mahila Visvavidyalayam, Tirupati-517 502, INDIA \\ *Corresponding author. E-mail: saraswathiphd@gmail.com
}

Received:J uly 10, 2013; Revised received: August 6, 2013; Accepted: August 10, 2013

\begin{abstract}
Diabetes mellitus is a serious public health problem worldwide. Diabetic foot ulcers (DFU), a major complication in Type 2 diabetes are one of the major causes of morbidity and mortality around the world. To screen various bacterial pathogens present in diabetic foot ulcers and to determine their antibiotic sensitivity to actinomycetes isolated from various fields of Chandragiri, Tirupati, twenty four actinomycetes isolates were isolated and screened by primary and secondary screening methods to determine potent antibiotic producers by using test organisms. Among 24 isolates, 4 were more potent and they showed varied range of antibacterial activity of pathogens, isolated form diabetic foot ulcers. Four isolates were compared with lenezoid antibiotic. Enterococcus was resistant to lenezoid antibiotic but four actinomycetes inhibited the growth of Enterococi.
\end{abstract}

Keywords: Actinomycetes, Diabetic foot ulcers, Lenezoid, Antibacterial activity

\section{INTRODUCTION}

Diabetes mellitus is a chronic disorder of the endocrine system which plaques approximately 17 million people nationwide (Siva Kumari and Shanthi, 2009; Ozer et al., 2010). Diabetic foot ulcers (DFU) are a major complication in Type 2 diabetes are one of the major causes of morbidity and mortality around the world. It occurs in $15 \%$ of all patients with diabetes and precedes $84 \%$ of all lower leg amputations (Bakker et al., 2005). Major increase in mortality among diabetic patients, observed over the past 20 years is considered to be due to the development of macro and micro vascular complications, including failure of the wound healing process. A diabetic foot ulcer involves repeated infections due to aerobes, anaerobes or fungi or in combinations (Siva Kumari and Shanti, 2009). Often these organisms interact with each other and form biofilms which is difficult to treat, enhancing antimicrobial resistance and lead to nonhealing ulcer. The microorganisms that occur on foot ulcers generally are Staphylococcus aureus, Streptococcus pyogens arising from the patient's own skin and Enterococci from bowel, Pseudomonas sp, Enterococcus sp and Proteus sp. carry a special role and are responsible for continuing and extensive tissue destruction with the poor blood circulation of the foot (Pathare et al., 1998; Anandi et al., 2004). The increasing association of multi-drug resistant (MDR) pathogens with diabetic foot ulcers for further compounds the challenge faced by the physician in treating diabetic ulcers without amputation (Yoga et al., 2006).

Screening of microorganisms for the production of novel antibiotics has been intensively pursued for many years by scientist (Tara Devi et al., 2009; Naikpatil and Rathod, 2011). Antibiotics have been used in many fields including agriculture, veterinary and pharmaceutical industry. Actinomycetes have the ability to synthesize many different biologically active secondary metabolites such as antibiotics, herbicides, pesticides, anti-parasitic and enzymes like cellulose and xylanases used in the waste water treatment. Of these compounds, antibiotics predominate in therapeutic and commercial importance (Lacey, 1973; Mc-Carthy and Williams, 1990; Ouhdouch et al., 2001; Saadoun and Gharaibeh, 2003). The present study was aimed to isolate actinomycetes from soil and to test for their antibacterial activity against the bacterial pathogens of the diabetic foot ulcers.

\section{MATERIALS AND METHODS}

I solation of actinomycetes: Soil samples were collected from the various fields of Chandragiri near Titupati of Chittoor District, Andhra Pradesh. All the soil samples were subjected to serial dilution method by using starch casein agar medium (SCA) (Johnson and Curl, 1972). Twenty four isolates were isolated and named as $\mathrm{Ms}_{1}$, $\mathrm{Ms}_{2}$ and so on. Various biochemical tests were performed for the identification of the actinomycete isolates. All isolates were screened to select a potent isolate to carry out further work.

Pathogens of DFU: Pure cultures of bacterial pathogens ISSN : 0974-9411 (Print), 2231-5209 (Online) All Rights Reserved @ Applied and Natural Science Foundation www.ansfoundation.org 
of diabetic foot ulcers were collected from the Department of Microbiology of S.V. Medical College, Tirupati, Andhra Pradesh. Pathogens include Staphylococcus aureus, Escherichia coli, Primilidium, Enterococci, Pseudomonas and Klebsiella.

Screening of actinomycetes for antibacterial activity:

Screening was performed in two parts - primary screening and secondary screening.

Primary screening:Twenty four isolates were subjected to primary screening by perpendicular streak method using Bacillus, Staphylococcus, Escherichia coli, Klebsiella and Pseudomonas as test organisms to select a potent antibiotic producing isolate. Among the 24 isolates, 11 isolates showed maximum inhibition of test organisms compared to others.

Secondary screening: Eleven isolates were separately inoculated to starch casein broth and incubated at $37^{\circ} \mathrm{C}$ under continuous shaking for 7 days. After incubation period, the content of the flask filtered through Whatman No. 1 filter paper. Then the filtrate used as a crude antibiotic extract. The test organisms were spread over the nutrient agar medium separately. Then wells were made by using cork borer and $50 \mu 1$ of the crude extract was added to the each well and incubated at $37^{\circ} \mathrm{C}$ for 24 hrs. Among the seven isolates $4\left(\mathrm{Ms}_{1}, \mathrm{Ms}_{2}, \mathrm{Ms}_{3}\right.$ and $\left.\mathrm{Ms}_{4}\right)$ isolates showed maximum inhibition of the test organisms compared to others and they were selected for further study.
Extraction of antibacterial metabolites: $250 \mathrm{ml}$ of starch casein broth was inoculated with above four isolates separately and incubated at $37^{\circ} \mathrm{C}$ for 7 days on continuous shaking. After incubation, the content of the flasks were filtered through Whatman No.1 filter paper. An antimicrobial compounds were extracted from the culture filtrate by solvent extraction method of Westly et al (1986). Ethyl acetate was added to the filtrate in the ratio of 1:1 $(\mathrm{v} / \mathrm{v})$ and shaken vigorously for 1 hour for complete extraction. The organic phase was separated and evaporated to dryness by keeping at $80-90^{\circ} \mathrm{C}$ on water bath. The residue was dissolved in $1 \mathrm{ml}$ of ethyl acetate. A ntimicr obial activity of the actinomycetes against DFU bacterial pathogens: Antimicrobial activity was performed in Muller-Hinton agar medium by using well method (Sen et al., 1995). After medium solidified, microbial pathogens were spread on the medium and wells were made with the help of the cork borer and they were sealed to prevent the leakage of the extract. To this wells the above extract was loaded and incubated at $37^{\circ} \mathrm{C}$ for $24 \mathrm{hrs}$. All the above antimicrobial extracts were compared with the linezolid antibiotic which is commonly used in the treatment of DFU.

\section{RESULTS AND DISCUSSION}

The prevalence of the diabetes is increasing in India faster than the other countries in the world. There are about 33 million diabetics mainly from the urban population.

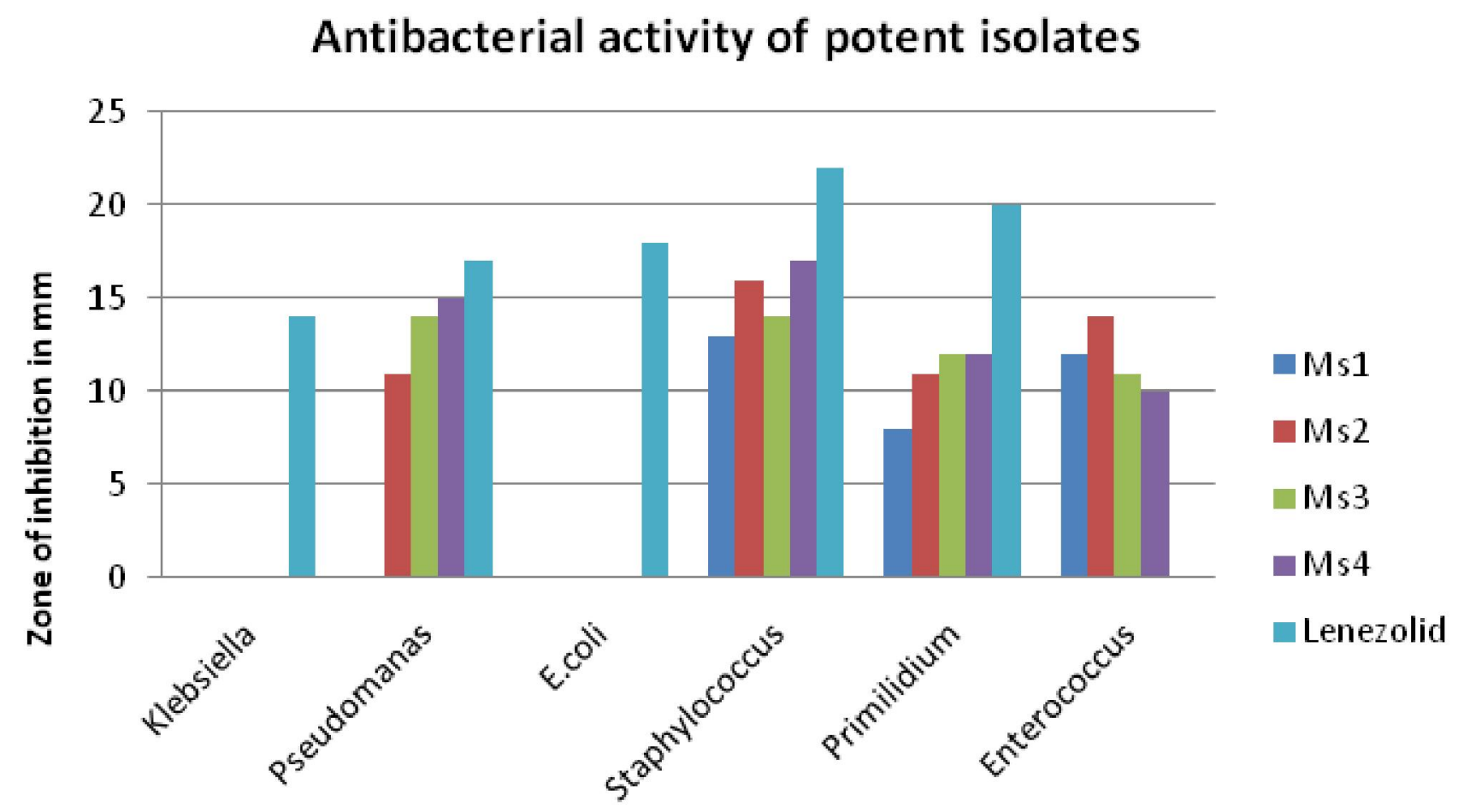

Test pathogens

Fig 1. Antibacterial activity of differ ent isolates of actinomycetes. 
Diabetes affects many other organs of the body but our study was carried out only on the diabetic foot infections of the affected patients in Tirupati, India. Peripheral vascular disease and neuropathy and other risk factors promotes the development of the diabetic foot ulcers with infection that can spread rapidly and lead to tissue destruction and subsequently amputation (Edmonds and Foster, 2004).

Twenty four isolates were isolated from the soil and were subjected to primary and secondary screenings to select potent antibiotic producers. Among the 24 isolates, 4 isolates showed maximum inhibition of test cultures like Bacillus, Staphylococcus, Escherichia coli, Klebsiella and Pseudomonas, respectively (Oskay et al., 2004; Dhananjeyan et al., 2010; Ozer et al., 2010). Four isolates $\left(\mathrm{Ms}_{1}, \mathrm{Ms}_{2}, \mathrm{Ms}_{3}\right.$ and $\left.\mathrm{Ms}_{4}\right)$ inhibited the growth of the pathogens of diabetic foot ulcers. Among the four isolates, $\mathrm{Ms}_{4}$ isolate showed maximum inhibition of all the pathogen, except E.coli compared to others and followed by $\mathrm{Ms}_{3}, \mathrm{Ms}_{2}$, and $\mathrm{Ms}_{1}$, respectively (Fig. 1). E.coli and Klebsiella were resistant to all the actinomycetes, but they are controlled by linezolid antibiotic. Enterococci were resistant to linezolid antibiotic, but controlled by the antimicrobial extracts of the all the four actinomycetes isolates.

The search for novel metabolites especially from actinomycetes requires a large number of isolates (over thousands) in order to discover a novel compound of pharmaceutical interest. The search will be more promising if divers actinomycetes are sampled and screened. For this reason, soils were specifically collected under identified farming soils. This is based on the hypothesis that actinomycetes diversity may be influenced by the diversity of cultivated plant species as these bacteria grow profusely in the humus and leaf litter layer. Furthermore, different plants produce different type of secondary metabolites and some of these chemical compounds are toxic to soil microorganisms including actinomycetes. However, adaptation has in turn leaded the actinomycetes to produce their own secondary metabolites.

It was concluded that among 24 isolates, isolated from soil of fields of Chandragiri near Titupati of Chittoor District, four isolates were potent. Enterococcus was resistant to lenezoid antibiotic while four actinomycetes inhibited the growth of Enterococi.

\section{REFERENCES}

Anandi, C., Alaguraja, D., Natarajan, V., Ramanathan, M., Subramaniam, C.S., Thulasiaram, M. and Sumithra, S. (2004). Bacteriology of diabetic foot lesions. Indian J our nal of Medical Microbiology, 22 (3): 175-178.

Bakker, K., Van Houtum, W. H. and Riley, P. C. (2005). The international diabetes federation focuses on the diabetic foot.
Curr Diab Rep, 5: 436-440.

Dhananjeyan, V., Selvan, N. and Dhanapal, K. (2010). Isolation, characterization and antibiotic sensitivity of actinomycetes from Locally (Near MCAS) collected soil samples. J ournal of Biological Sciences, 10 (6): 514-519.

Edmonds, M.E. and Foster, A. (2004). The use of antibiotics in the diabetic foot. Am. J. Surg., 187: S25-S28.

Johnson, L.F. and Curl, E.A. (1972). Methods for research on the ecology of soil-borne plant pathogens. Burgess Publishing Company, Minneapolis. 247pp.

Lacey, J. (1973). Actinomycetales: Characteristics and practical Importance. Edited by Sykes, G. and Skinner, F. The society for Bacteriology Symposium Series, Academic press London- New York No.2.

Mc-Carthy, A.J. and Williams, S.T. (1990). Methods for studying the ecology of Actinomycetes. Methods in Microbiology. Ed. By Grigorova and Norris, J.R. Academic Press Limited. London, 22:533-363.

Naikpatil, S.V. and Rathod, J.L. (2011). Selective isolation and antimicrobial activity of rare actinomycetes from mangrove sediment of Karwar. J ournal of E cobiotechnology, 3 (10): 48-53.

Oskay, M., Tamer, A.U., and Azeri, C. (2004). Antibacterial activity of some actinomycetes isolated from forming soils of Turkey. African J ournal of Biotechnology, 3: 441-446.

Ouhdouch, Y., Barakate, M. and Finanse, C. (2001). Actinomycetes of Moroccan habitats: Isolation and screening for antifungal activities. Eur.J. Soil Biol., 37: 69-74.

Ozer, B., Kalaci, A., Semerci, E., Duran, N., Davul, S., and Yanat, A.N. (2010). Infections and aerobic bacterial pathogens in diabetic foot. African J ournal of M icrobiology Research, 4: 2153-2160.

Pathare,N. A., Bal, A., Talvalkar, G.V. and Antani, D.U. (1998). Diabetic foot infections: a study of microorganisms associated with the different Wagner gardens. Indian J.Pathol.Mocrobiol., 41:437-441.

Saadoun, I. and Gharaibeh, R. (2003). The Streptomyces flora of Badia region of Jordan and its potentials as a source of antibiotics active against antibiotic-resistant bacteria. J .Arid. Environ., 53:365-371.

Sen., K.S., Haque, F.S. and Pal, C.S. (1995). Nutrient Optimization for production of broad spectrum antibiotics by Streptomyces. Antibiotics Str. 15.4. Acta. Microbial. Hung., 42:155-162.

Siva Kumari, V. and Shanthi, G. (2009). Antibiotic susceptibility of common bacterial pathogens isolated from diabetic pus. Advanced Biotech., 10-13.

Tara Devi, G., Sherpa, C., Viswanath, P.A. and Bind, L. (2009). Isolation and characterization of antibacterial actinomycetes from soil samples of Kalapattar, Mount Everest Region. Nepal J ournal of Science and Technology, 10:173-182.

Westly, J.W., Ecans, R.H., Sello, R.H., Troupe, N., Liu, C.M., Blount, J.F. (1986). Isolation and characterization of antibiotic X-1454 A, a novel monocarboxylic acid ionophore produced by Streptomyces antibioticus NRRL 18167. J Antibioti. Tokyo, 32(2):100-107.

Yoga, R., Khairul, A. Sunita, K. and Suresh, C. (2006). Bacteriology diabetic foot lesions. M ed. J . M alaysia, 61:614 